\title{
フェンスによる超音速空力干渉を利用したカプセル分離*1 Improvement in Capsule Abort Performance Using Supersonic Aerodynamic Interaction by Fences
}

\author{
香 山寛 人 $* 2 \cdot$ 汪 運 鵬*2 $\cdot$ 小澤 啓 伺 $* 3 \cdot$ 土井 克 則 $* 4 \cdot$ 中 村 佳 朗 $* 4$ \\ Hiroto Koyama, Yunpeng Wang, Hiroshi Ozawa, Katsunori DoI and Yoshiaki Nakamura
}

Key Words : Aerodynamic Interaction, Supersonic Flow, Launch Abort System, Capsule-Type Space Transportation, Fence

\begin{abstract}
The space transportation system will need advanced abort systems to secure crew against serious accidents. Here this study deals with the capsule-type space transportation systems with a Launch Abort System (LAS). This system is composed of a conic capsule as a Launch Abort Vehicle (LAV) and a cylindrical rocket as a Service Module (SM), and the capsule is moved away from the rocket by supersonic aerodynamic interactions in an emergency. We propose a method to improve the performance of the LAV by installing fences at the edges of surfaces on the rocket and capsule sides. Their effects were investigated by experimental measurements and numerical simulations. Experimental results show that the fences on the rocket and capsule surfaces increase the aerodynamic thrust force on the capsule by $70 \%$ in a certain clearance between the capsule and rocket. Computational results show the detailed flow fields where the centripetal flow near the surface on the rocket side is induced by the fence on the rocket side and the centrifugal flow near the surface on the capsule side is blocked by the fence on the capsule side. These results can confirm favorable effects of the fences on the performance of the LAS.
\end{abstract}

\section{1. 緒 論}

宇宙輸送の商業化をはじめとする宇宙利用の活性化にお いて, 安全な宇宙輸送システムの確立が急務である ${ }^{11}$ 。これ までの宇宙輸送システムは, スペースシャトルに代表される 再使用型のものと, アポロ (Apollo) やソユーズ (Soyuz) のようなカプセルを用いた使い切りロケットによるものに 分類される。これらはいずれも優れた技術を持った宇宙輸 送システムではあるが，それぞれ課題を有する。

再使用可能なスペースシャトルは, この 30 年間宇宙輸 送の主力として利用されてきた。しかし，再使用に伴う機 体や飛行システムの老朽化に加えて, 搭乗員の緊急脱出シ ステム (LAV : Launch Abort Vehicle) 2 2 4) を持たないこ とが安全上重大な課題であった。 実際に発生した 1986 年 のチャレンジャー号打ち上げ時の爆発事故や 2003 年のコ ロンビア号大気圈再突入後に扔ける空中分解事故 ${ }^{5)}$ によっ て, これらの課題は広く認知され, 結果として 2011 年の スペースシャトル引退の要因の一つとなった.

一方, カプセル式の宇宙輸送システムは, 緊急脱出シス テムの搭載が比較的容易であり, 例えば, 脱出用ロケット 等を用いて, 緊急時に搭乗員が乗ったカプセルをメインロ ケットから離脱させることで, 搭乗員の安全を確保できる 可能性がある，ただし，カプセルがロケットから離脱する

\footnotetext{
*1 (C) 2012 日本航空宇宙学会

平成 23 年 3 月 22 日原稿受付

*2 名古屋大学大学院工学研究科

*3 ドイツ航空宇宙センター

$* 4$ 名古屋大学工学部
}

過程に扔いて, 二物体間の複雑な流机に起因して各々に想 定外の空気力が作用する結果， ロケットから離脱するカプ セルに十分な推力が㗢かず，一旦離脱したカプセルが再び ロケットに衝突する再接触 (Recontact) 2) の危険性も存在 する。この現象は, 打ち上げ中の動圧が高い低高度で生じ やす(6).

小澤らては, この二物体間の空力干渉を逆に利用して, 空 気力のみで二物体を分離できる可能性を示した。 具体的に は, 円錐形のカプセルと円柱形のロケットを仮定し, カプ セル底面の 1.5 倍の径を有するディスクをロケットの先端 面に付加することで空力干渉の状態を恋化させた，その結 果として, 複数の所定の二物体間隔に扔いて, カプセル底 面の圧力が大きく上昇し, カプセルをロケットから引き離 すような空気力がカプセルに作用することを示した.

このような空力干渉の特性は非常に有用であるが, カプ セルを危険な領域から素早く離脱させるために，あるいは， それを補助する推進システムを小型化するためには，その 空気力はできるだけ大きくすることが望まれる.

本研究では, カプセルに作用する空気力をさらに増加さ せるために, デイスクに加えて, ロケット前面やカプセル底 面の円周上にフェンスを取り付けることを提案する。 その 効果を超音速風洞による実験と数值シミュレーションによっ て定量的に評価すると共に, その力学的構造を解明する.

\section{2. 実 験 方 法}

2.1 模型 本研究で用いた実験模型の形状を第 1 図に 示す。第 1 図 (a) はフェンスが無い場合の形状である，底面 


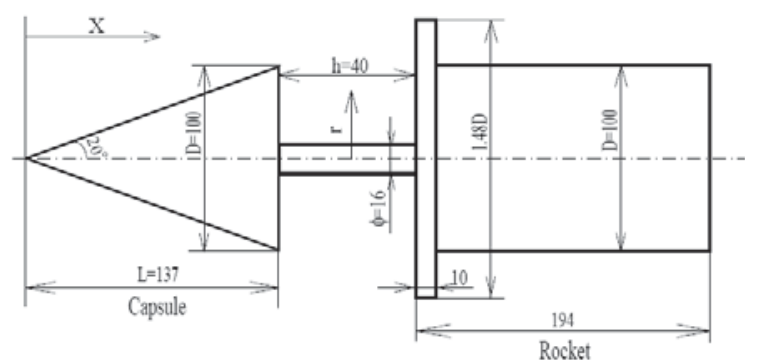

(a)フェンスが無い場合（No fence）

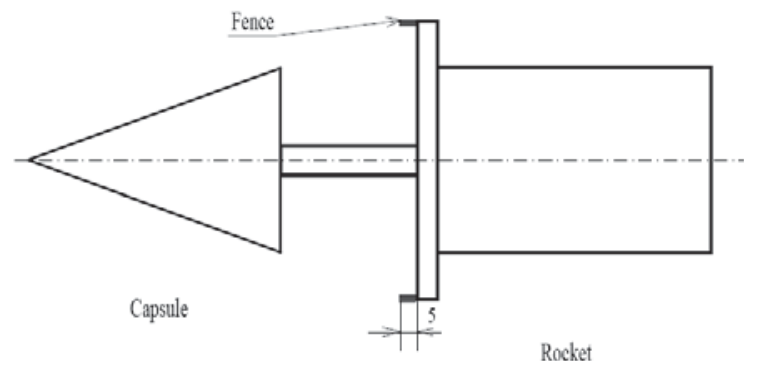

(b) ロケット側にフェンスがある場合（One fence）

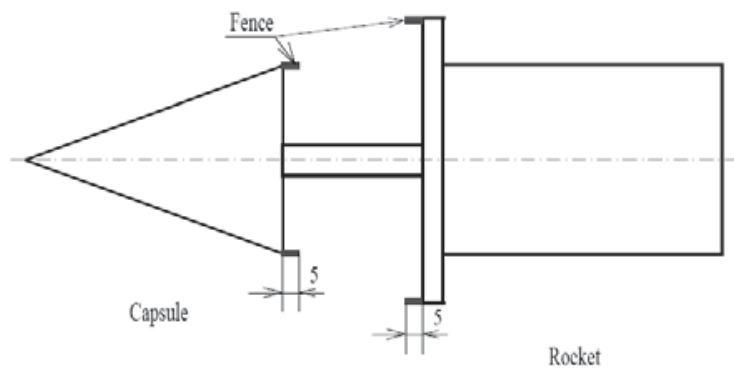

(c) 両側にフェンスがある場合（Two fences）

第1図 実験模型

第 1 表 超音速風洞の通風条件（ISAS/JAXA）

\begin{tabular}{ccccc}
\hline$M_{\infty}$ & $R e$ & $P_{0}[\mathrm{kPa}]$ & $P_{\infty}[\mathrm{kPa}]$ & $T_{0}[\mathrm{~K}]$ \\
\hline 3.0 & $1.6 \times 10^{7}$ & $2.2 \times 10^{2}$ & 6.0 & 292 \\
\hline
\end{tabular}

直径 $D=100 \mathrm{~mm}$, 半頂角 $20^{\circ}$ のカプセルを模擬した円錐 と, 直径 $D=100 \mathrm{~mm}$ のロケットを模擬した円柱を, $\phi 16$ の円柱で接続する。 また， ロケットの前面に直径 $148 \mathrm{~mm}$ $(1.48 D)$ の円板形状のディスクを取り付ける。 デイスクの 断面積はカプセルの底面積の 2.2 倍である. さらに, カプセ ルとデイスクの間隔は $h=40 \mathrm{~mm}(h / D=0.40)$ とする.

第 1 図 (b) はデイスク前面の外周上にフェンスを取り付 けた場合, 第 1 図 (c) はデイスク前面およびカプセル底面の 外周上にフェンスを取り付けた場合の形状である。各フェ ンスの高さは $5 \mathrm{~mm}$ ，厚さは $1 \mathrm{~mm}$ とする.

2.2 実験方法 本研究では, JAXA 宇宙科学研究本部 （ISAS/JAXA）の吹き出し式超音速風洞を使用する。 その テストセクションの断面サイズは $600 \mathrm{~mm} \times 600 \mathrm{~mm}$ であ る。 その通風条件を第 1 表に示す。試験気体は空気であり, 一様流のマッ八数は $M_{\infty}=3.0$, カプセル全長を代表長さ とするレイノルズ数は $R e=1.6 \times 10^{7}$ である，なお，一様 流に対する模型中心軸の迎角は $0^{\circ}$ としている.

前述の模型を本風洞に設置し, シュリーレン法によって
空力干渉流れ場を可視化すると共に, 圧力センサによって 模型表面上の静圧分布を計測する。

\section{3. 計 算 方 法}

3.1 計算条件 本研究では, 実験模型が軸対称形状で あり, かつ流れ場の主要な構造の理解を目的としているた め, 流れ場を軸対称と仮定して計算する。物体形状は第 1 図に示す形状と同じである，計算格子の七ル数は約 15 万 である。

気体は空気とし，適切な物性值を与える。一様流の条件 は第 1 表に示す条件と同じである.

3.2 計算方法 流体の支配方程式は, 圧縮性 NavierStokes 方程式である。気体は完全気体とする。また，乱流 モデルとして, Baldwin-Lomax モデルを適用する，空間 の離散化には有限体積法を用い, 非粘性流束は Roe の近似 Riemann 解法, 粘性流束は中心差分法によって, それぞれ 求める。なお， セル境界での物理量は, Van Albada の制 限関数を加えた MUSCL 法によって決定される。 また，時 間積分には 2 次精度の Runge-Kutta 法を用いる。なお，上 述の計算格子および計算方法は, 小澤ら7)が用いたものと 同様である。そこでは, 実験結果との比較から計算結果が 妥当であることを示している。 また，複数の解像度の格子 による計算結果を比較することで格子収束性を確認し, 本 研究が注目している現象を捉える上では, 格子の解像度が 十分であることを示している.

\section{4. 実 験 結 果}

4.1 空力干渉流れ場 シュリーレン法による可視化に ついて, フェンスが無い場合（No fence）を第2図 (a)に, 両側にフェンスがある場合（Two fences）を第 2 図 (b)に それぞれ示す。この図で色が暗い領域ほど密度勾配が大き い.また, 可視化結果から推定される流れ場の概要を第 3 図 (a), (b) にそれぞれ示す.

フェンスが無い場合（第 2 図 (a), 第 3 図 (a)), 円錐形の カプセル先端から発生する斜め衝撃波に加えて, カプセル の底面端部からも圧縮波が生じていることが分かる。これ らの圧縮波によって，その下流で静圧は大きく増加すると 共に，二つの波は衝撃波・衝撃波干渉を起こす。また，カプ セル底面端部から発生したせん断層は, その背後のロケット 前面に取り付けたディスクの端部付近に向かって伸び，その 先では弓状衝撃波（bow shock）が発生する。これにより, デイスク前面の端部付近では静圧がさらに上昇する。また, この衝撃波とカプセル先端からの斜め衝撃波がデイスクよ りも下流側で衝撃波・衝撃波干渉を起こす 8,9 . 小澤ら ${ }^{7,8)}$ は，ロケットの上面に径の大きなディスクを取り付けるこ とによって，上述の空力干渉をより強くして，カプセルを ロケットから引き離すような空気力を与えることを実現し ている.

ディスク前面およびカプセル底面の外周上にフェンスを 取り付けた場合（Two fences）の流れ場を第 2 図 (b) 拈よ び第 3 図 (b) に示す。フェンスが無い場合と同様に, カプ 


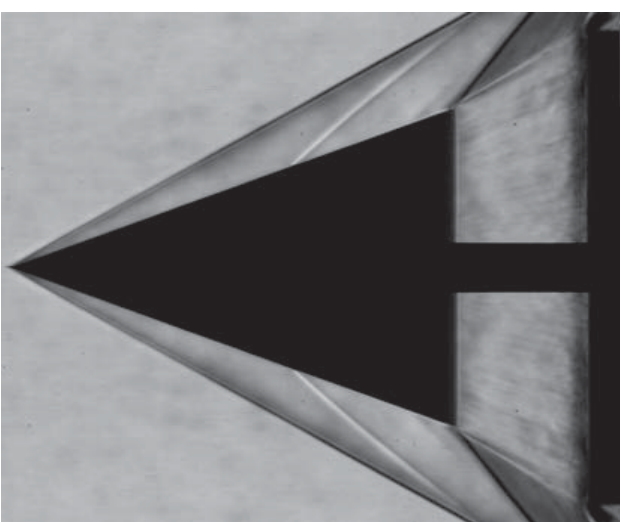

(a) フェンスが無い場合（No fence case）

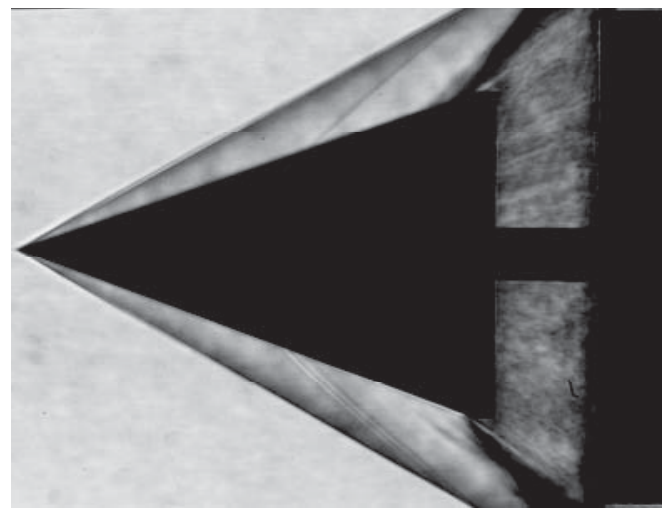

（b）両側にフェンスがある場合（Two fences case）

第 2 図 空力干渉流れ場のシュリーレン可視化結果

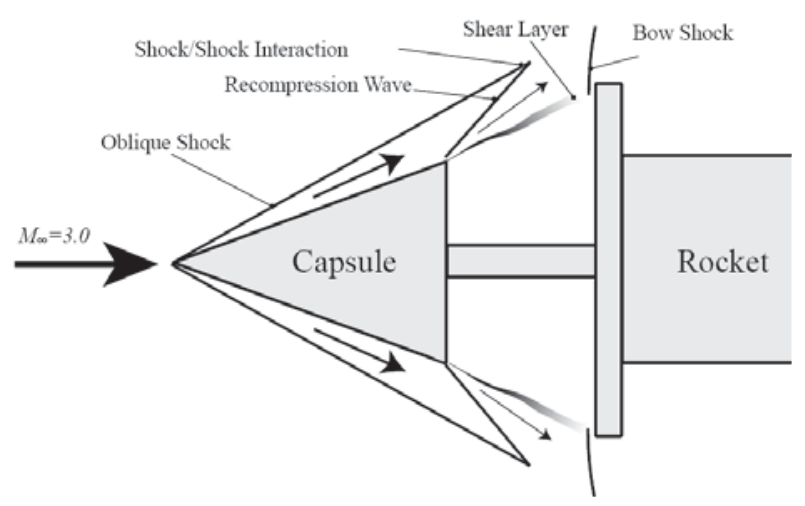

(a) フェンスが無い場合（No fence case）

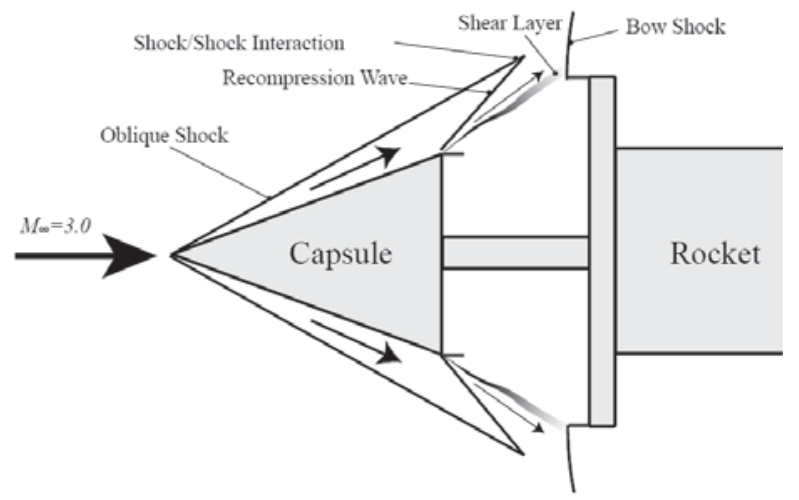

(b) 両側にフェンスがある場合 (Two fences case)

第 3 図 空力干渉流れ場の概要
セル先端から発生する斜め衝撃波, カプセルの底面でフェ ンスと結合する端部から発生する圧縮波，せん断層が確認 できる。すなわち，流れ場の基本的な構造はフェンスの有 無によって変化しない. しかし, その圧縮波やせん断層は, フェンスの無い場合に比べて不鮮明である。 また, カプセ ルとディスクに挟まれた隙間部において，明暗部がまだら 状に分布している様子が分かる。これは，カプセル底面部 付近からの圧縮波やせん断層が振動していること，および 隙間部での物理量分布がより激しく乱れていることを示唆 する。

4.2 カプセルとディスクに作用する空気力 フェンスが 無い場合 (No fence), ディスク前面にフェンスがある場合 (One fence), カプセル底面とディスクの両側にフェンス がある場合（Two fences）における物体表面上の静圧分布 を調べる。第 4 図 (a) はカプセル底面の時間平均静圧の半 径方向分布で，第 4 図 (b) はディスク前面での同分布であ る。なお，両図の横軸は中心軸からの距離をカプセル底面 の直径 $D$ で無次元化している．また，第 4 図 (a)には円錐 周りの流れに関する Taylor-Maccoll の理論式10)より導出 したカプセル前面での静圧值も示す。本実験条件では, カ プセル前面の静圧は一様流静圧の約 3 倍である.

両図を見ると，ディスク前面の端付近を除いて，カプセ ル底面およびディスク前面での静圧分布の時間平均はほぼ 一様であることが分かる。また，フェンスの有無にかかわ らず，その静圧值はカプセル前面での静圧よりも高い.

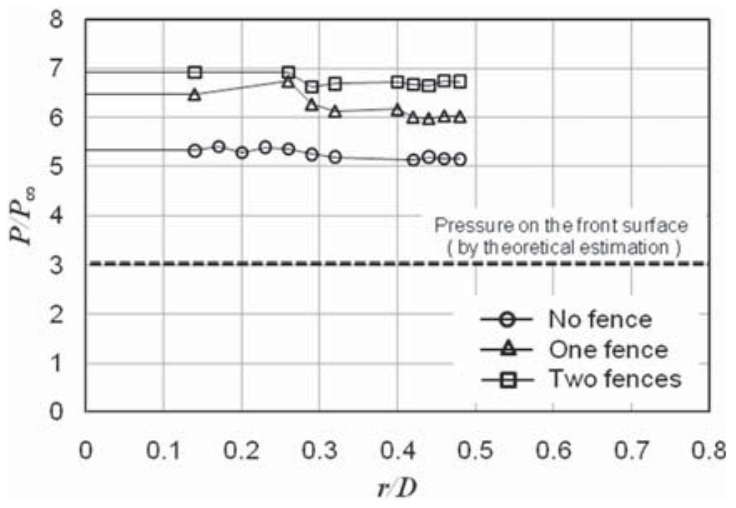

(a) カプセル底面

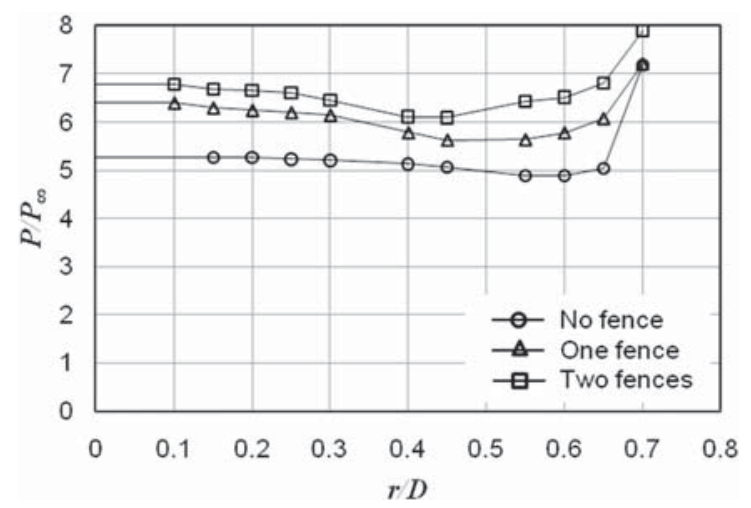

(b) デイスク前面

第 4 図 時間平均表面静圧分布の計測結果 


\begin{tabular}{|c|c|c|}
\hline & $\begin{array}{c}\text { Capsule } \\
C_{D}\end{array}$ & $\begin{array}{c}\text { Rocket } \\
C_{D}\end{array}$ \\
\hline No fence & -0.35 & 0.86 \\
\hline One fence & -0.50 & 0.97 \\
\hline Two fences & -0.59 & 1.06 \\
\hline
\end{tabular}

この静圧上昇は, フェンスの存在によってさらに大きく なる。例えば，カプセル底面での静圧分布について，フェ ンスが無い場合（No fence）は一様流静圧の 5 倍程度であ るのに対して，ディスク前面にフェンスがある場合（One fence）は, 一椂流静圧の 6 倍程度に, さらに両側にディス クがある場合（Two fences）には一様流静圧の 7 倍程度ま で静圧が上昇する.

第 4 図に示す静圧分布から算出される抵抗係数を第 2 表 に示す. カプセル， ロケット共に，正の抵抗係数は前面か ら後方へ抗力が作用していることを表す。な抄，抵抗係数 の算出に打いて, カプセル前面の静圧值は前述のように理 論式から導出し、 ロケットのベース圧は一様流静圧に等し いと仮定している.

第 2 表を見ると，カプセルには前方への空気力が，ロケッ トには後方への空気力がそれぞれ作用し，その空気力の大 きさはフェンスによってさらに増加することが分かる。例 えば, フェンスが無い場合（No fence）に比べて, フェンス が両側にある場合（Two fences）のカプセルに作用する推 力は約 70\%， ロケットに作用する抗力は約 $20 \%$ 増加する. すなわち, カプセルとロケットの間には空力干渉の結果と して両者を引き離す斥力が作用し，それはフェンスによっ てさらに大きくなる。このように, 空力干渉を活用したカ プセル緊急分離システムに扔いて, 本研究が提案するフェ ンス形状の空力デバイスは非常に効果的である.

\section{5. 計 算 結 果}

本研究では, 流れ場の詳細および静圧上昇のメカニズム を明らかにするため, 実験と併せて数值解析を行った。 そ の結果を以下に示す。

5.1 実験結果との比較 初めに, 実験結果と比較する ことで，計算結果の妥当性を示す。

ある瞬間に㧍ける密度勾配の分布について，フェンスが 無い場合（No fence）を第 5 図 (a)に，両側にフェンスが ある場合（Two fences）を第 5 図 (b) にそれぞれ示す。第 2 図と同様に, 色が暗い領域ほど密度勾配が大きい領域を示 す. 図を見ると, どちらの場合においても, カプセルの先 端から発生する斜め衝撃波, カプセルの底面でフェンスと 結合する端部から発生する圧縮波やせん断層, およびディ スク前面端付近の弓状衝撃波が現れており, その概要は第 2 図に示す実験結果とよく一致する。

物体表面上の静圧分布について, フェンスが無い場合 (No fence), ディスク前面にフェンスがある場合 (One fence), 両側にフェンスがある場合（Two fences）に扔けるカプセ 儿底面の時間平均静圧の半径方向分布を第 6 図 (a)に, デイ スク前面の同分布を第 6 図 (b) にそれぞれ曲線で示す。ま

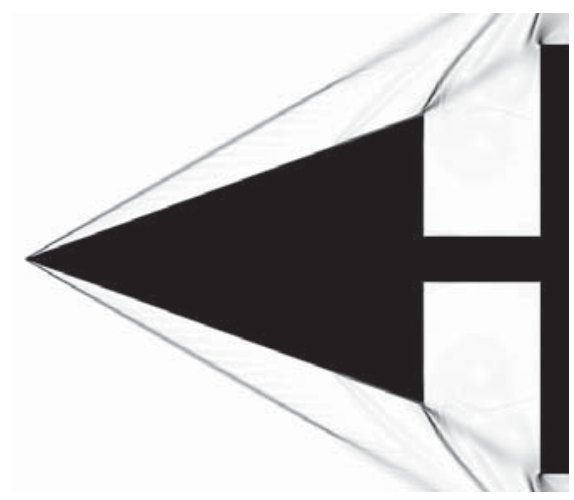

(a) フェンスが無い場合（No fence）

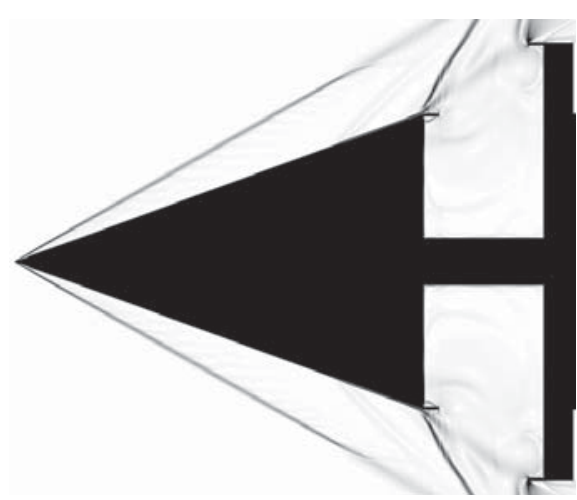

(b) 両側にフェンスがある場合（Two fences） 第 5 図 密度勾配分布の計算結果

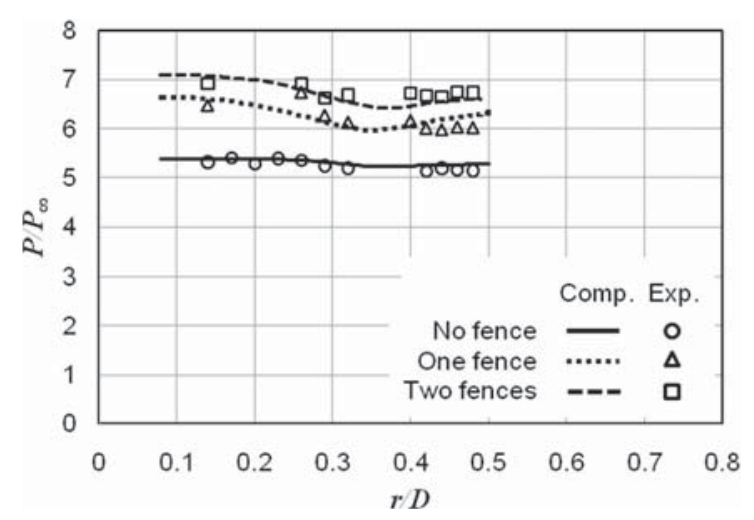

(a) カプセル底面

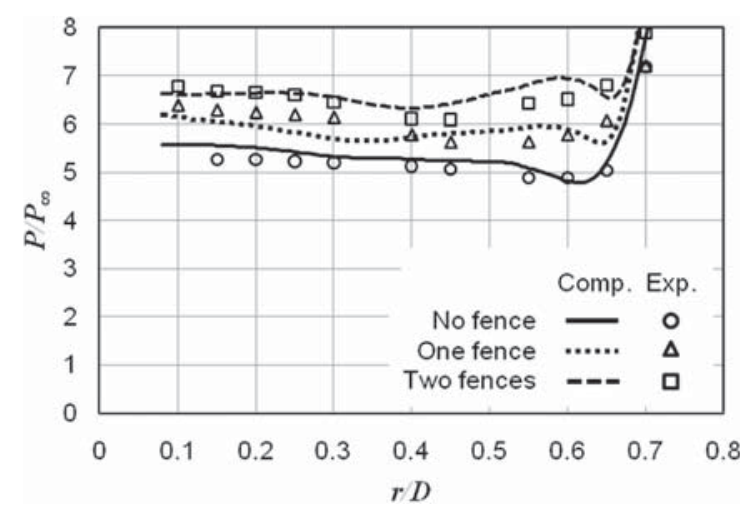

(b) ディスク前面

第 6 図 時間平均表面静圧分布の計算結果 


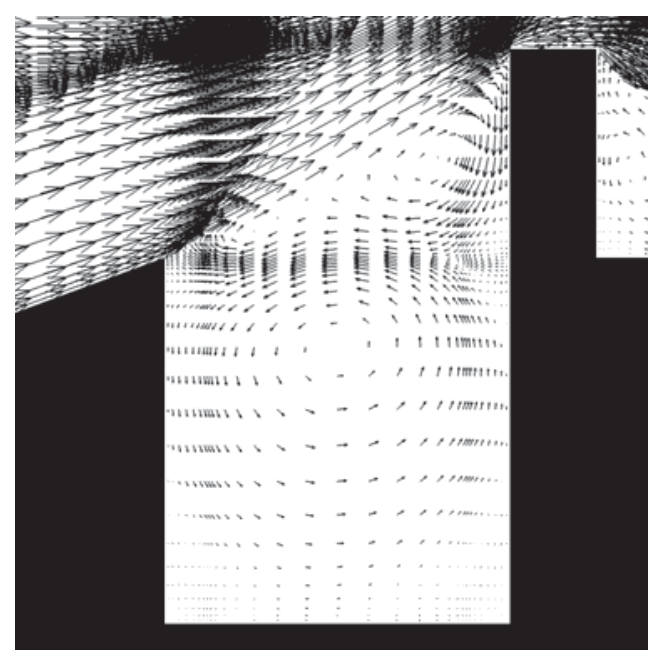

(a) フェンスが無い場合（No fence）

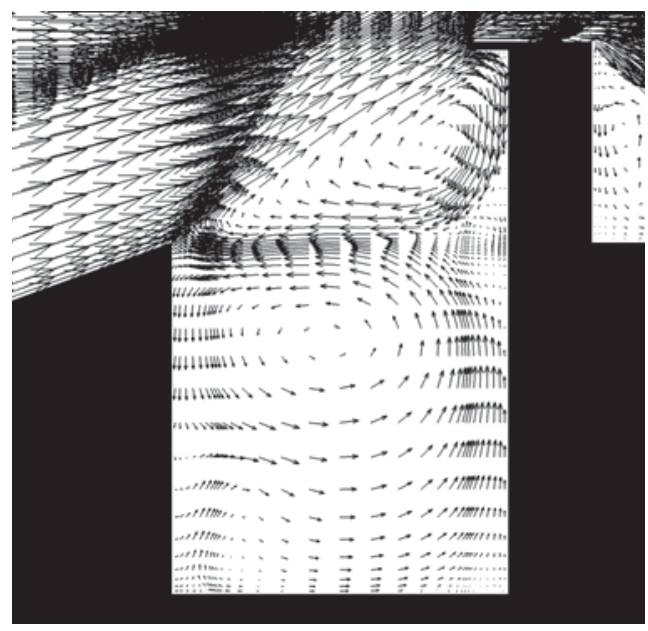

（b）ロケット側にフェンスがある場合（One fence）

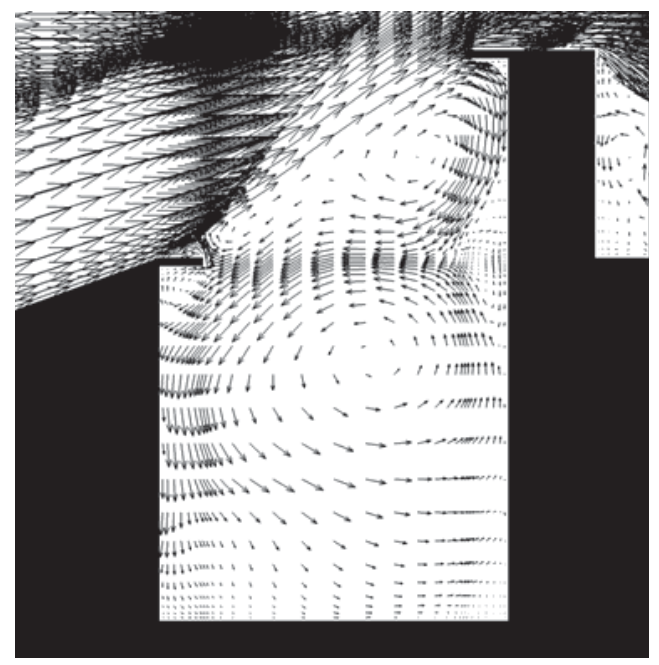

(c) 両側にフェンスがある場合 (Two fences)

第 7 図 カプセル・ディスク間における速度ベクトル分布の計算結果

た，第 4 図 (a) 㧍よび (b) に示した実験結果も同図にそれ ぞれシンボルで示す，実験結果と同様に，カプセル底面扔 よびディスク前面での時間平均静圧の分布は, デイスク前 面の端付近を除いてほぼ一様であり, その静圧值はフェン スの存在によって大きくなる。また，その值も実験結果と
比較的よく一致している.

以上の結果より計算結果が妥当であると判断し，その結 果に基づいて流れ場の詳細を解析する.

5.2 カプセルとディスクの間の流れ場 カプセルとロ ケットを引き離す働きをするカプセル底面とディスクに挟 まれた空間の流れ場について, ある瞬間での速度べクトル 分布を第 7 図に示す。フェンスが無い場合（No fence）を 第 7 図 (a)に，ディスク前面にフェンスがある場合（One fence）を第 7 図 (b)に, 両側にフェンスがある場合（Two fences）を第 7 図 (c) にそれぞれ示す.

どの場合においても，せん断層の下方に時計回りの渦が 形成され，その下方に反時計回りの剝離渦が誘起されるこ とが分かる ${ }^{11,12)}$. カプセル底面の端部から剝離した流れは, ディスク前面の端部に弓状衝撃波を伴って衝突する。これ により，第 4 図 (b) や第 6 図 (b) に示されるような大きな 静圧上昇が発生する。また，その流れの一部は内側に流れ 込んで剥離渦を形成する。この内側への流れは一様流と逆 の方向に向きを変え, カプセル底面の端部付近に到達した 後, その一部はさらに内側へ流れ込んで, 反時計回りの剝 離渦を形成する.

このとき，デイスク前面およびカプセル底面のフェンス は，流れを隙間の内側に引き达みやすくする役割を果たす。 第 7 図 (b), (c) を見ると, ディスク前面のフェンスがその 外側へ逃げる流れを妨げていることが分かる。 また，第 7 図 (c) を見ると, カプセル底面のフェンスが, 渦に沿った 逆流が外側へ流出するのを妨げていることが分かる.

ただし，ディスク前面にフェンスがある場合 (One fence) や両側にフェンスがある場合（Two fences）の計算結果で は，隙間内部の流れ場やカプセル後縁から発生する圧縮波 やせん断層が周期的に変動する現象が確認された。これは, 流れが衝突する箇所に設置されたフェンスが一時的に流れ を外側に導くことに起因する。

\section{6. ま と め}

本研究では, カプセル式宇宙輸送機における空力干涉を 利用した緊急分離システムの性能向上手段として, ロケッ 卜前面㧍よびカプセル底面にフェンスを取り付けることを 提案した，その有効性およびメカニズムを超音速風洞実験 と CFD の結果に基づいて明らかにした。

カプセル底面やロケットデイスク前面の外周上にフェン スを設置すると, カプセルに作用する推力やフェンスに作 用する抗力は大きく増加する。例えば，両方にフェンスを 設置した場合，カプセルに作用する推力は約 70\%， ロケッ トに作用する抗力は約 $20 \%$ 増加する。 このフェンスの効果 は，フェンスを付けることにより，カプセルとロケット間 の実質的な間隔が短くなり，その影響で，カプセル底面端 部から発生する斜め衝撃波の衝撃波角が大きくなり, 静圧 が上昇したことに起因する。

このフェンス形状の空力デバイスは, カプセルの緊急分 離システムに打ける簡素でパッシブな空力制御手段として, 非常に効果的で有用である. 


\section{参 考 文 献}

1) Dulepov, N. P., Lanshin, A. I., Sokolova, O. V. and Tjurikov, E. V.: Propulsion Systems for TSTO Airplane-Accelerators of Different Types, AIAA Paper 2001-1914, 2001.

2) Pandya, S., Onufer, J., Chan, W. and Klopfer, G.: Capsule Abort Recontact Simulation, NAS Technical Report, NAS06-005, 2006; see also AIAA Paper 2006-3324, 2006.

3) Davidson, J.: Crew Exploration Vehicle Ascent Abort Overview, AIAA Paper 2007-6590, 2007.

4) Hayes, W. P.: Crew Exploration Vehicle Launch Abort System Flight Test Overview, AIAA Paper 2007-6596, 2007.

5) Pulsonetti, M. V. and Thompson, R. A.: LAURA Aerodynamic Computations for Space Shuttle Columbia STS-107 Baseline and Damage Scenarios, AIAA Paper 2004-2278, 2004.

6) 今田高峰 : エスケープシステムを前提とした有人宇宙船の飛行経 路及び課題，第 51 回宇宙科学技術連合講演会講演集，2007.

7）小澤啓伺, 北村圭一, 森 浩一, 中村佳朗 : 超音速空力干渉を利 用したカプセル型宇宙輸送システムの緊急分離, 日本航空宇宙学
会論文集， 57 (2009), pp. 175-182.

8) Ozawa, H., Hanai, K., Kitamura, K., Mori, K. and Nakamura, Y.: Experimental Investigation of Shear-Layer/ Body Interactions in TSTO at Hypersonic Speed, AIAA Paper 2008-723, 2008

9) Edney, B.: Anomalous Heat Transfer and Pressure Distributions on Blunt Bodies at Hypersonic Speed in the Presence of an Impinging Shock, FFA Rep. 115, 1968.

10) Taylor, G. I. and Maccoll, J. D.: The Air Pressure on a Cone Moving at High Speeds, Proc. Roy. Soc. London A, 139 (1933), pp. 279-311.

11) Charwat, A. F., Roos, J. N., Dewey, C. F., Jr. and Hitz, J. A.: An Investigation of Separated Flows-Part I: The Pressure Field, J. Aerospace Sci., 28 (1961), pp. 457-470.

12) Charwat, A. F., Dewey, C. F., Jr., Roos, J. N. and Hitz, J. A.: An Investigation of Separated Flows-Part II: Flow in the Cavity and Heat Transfer, J. Aerospace Sci., 28 (1961), pp. 513-527. 